\title{
Towards medicine of excellence in Mexico: the "Código Infarto" protocol, a view from the perspective of translational bioethics
}

\section{Gabriela Borrayo-Sánchez, ${ }^{1}$ Abelardo Flores-Morales, ${ }^{2}$ Leonardo Salas-Collado and}

Myriam M. Altamirano-Bustamante ${ }^{3 *}$

${ }^{1}$ A Todo Corazón, Código Infarto Program; ${ }^{2}$ Cardiology Hospital; ${ }^{3}$ Metabolic Diseases Research Unit, Clinical Ethics Trans-functional Group. Centro Médico Nacional Siglo XXI, Instituto Mexicano del Seguro Social, Mexico City, Mexico

\begin{abstract}
Introduction: Mexico is the country with the highest mortality due to ST-elevation acute myocardial infarction (STEMI), and the IMSS has therefore developed the protocol of care for emergency departments called Código Infarto (Infarction Code). In this article, aspects of translational medicine are discussed with a bioethical and comprehensive perspective. Objective: To analyze the Código Infarto protocol from the perspective of translational bioethics. Method: A problem-centered approach was carried out through reflective equilibrium (or Rawls' method), as well as by applying the integral method for ethical discernment. Results: The protocol of care for emergency services Código Infarto is governed by evidence-based medicine and value-based medicine; it is guided by a principle of integrity that considers six dimensions of quality for the care of patients with STEMI. Conclusion: The protocol overcomes some adverse social determinants that affect STEMI medical care, reduces mortality and global economic disease burden, and develops medicine of excellence with high social reach.
\end{abstract}

KEY WORDS: Código Infarto. Acute myocardial infarction. Translational bioethics. Ethical dilemmas.

\section{Hacia una medicina de excelencia en México: el protocolo Código Infarto, una visión desde la bioética traslacional}

\section{Resumen}

Introducción: México es el país con mayor mortalidad por infarto agudo de miocardio con elevación del segmento ST (IAM CEST), por lo que el Instituto Mexicano del Seguro Social desarrolló el protocolo de atención para los servicios de urgencias denominado Código Infarto. En este artículo se discuten aspectos de la medicina traslacional con una perspectiva bioética e integral. Objetivo: Analizar el protocolo Código Infarto desde la perspectiva de la bioética traslacional. Método: Se realizó una aproximación centrada en el problema a través del equilibrio reflexivo, así como la aplicación del método integral para el discernimiento ético. Resultados: El protocolo de atención para los servicios de urgencias Código Infarto se rige por la medicina basada en la evidencia y la medicina basada en valores; se orienta por el principio de integridad que considera las seis dimensiones de la calidad para la atención de pacientes con IAM CEST. Conclusión: El protocolo supera algunos determinantes sociales adversos que afectan la atención médica del IAM CEST, disminuye la mortalidad, la carga económica global de la enfermedad y desarrolla una medicina de excelencia de alto alcance social.

PALABRAS CLAVE: Código Infarto. Infarto agudo de miocardio. Bioética traslacional. Dilemas éticos.

Correspondence:

${ }^{*}$ Myriam M. Altamirano-Bustamante

E-mail: biocatalisismma@gmail.com
Gac Med Mex. 2020;156:366-372

Contents available at PubMed

www.gacetamedicademexico.com

0016-3813/@ 2020 Academia Nacional de Medicina de México, A.C.. Published by Permanyer. This is an open access article under the CC BY-NC-ND license (http://creativecommons.org/licenses/by-nc-nd/4.0/). 


\section{Introduction}

In 2017, Mexico was considered the country with the highest mortality due to ST-segment elevation acute myocardial infarction (STEMI): $27.5 \%$ versus an average of $7.5 \%$ recorded by the Organization for Economic Cooperation and Development (OECD) that year, with the National Institute of Geography reporting 141,619 deaths associated with cardiovascular diseases. This is relevant considering that economic resources are limited: in 2017 , only $5.5 \%$ of the gross domestic product (GDP) in Mexico was assigned to health, with 2.4 doctors per thousand population being reported, in comparison with 3.4 per thousand population indicated by OECD; in addition, per capita expenditure was 4 times lower than the average. ${ }^{1-3}$ There are other social determinants that affect health care, such as lack of accessibility, heterogeneity of social and institutional regulations, and inequity in the provision of services; ${ }^{4}$ there are few health policies that improve care and translate their results into a mortality reduction.

Some comprehensive management models have reduced mortality through care protocols, which are a bridge between evidence-based medicine and value-based medicine (best practices applied in the provision of care). ${ }^{5}$ Facilitating the transition from research to a clinical application with health benefits is known as translational medicine and allows the free transit of knowledge to deal with current health challenges. ${ }^{6}$ The purpose of this work is to analyze the protocol of care for emergency departments called Código Infarto (Infarction Code) from the perspective of translational bioethics, since its implementation has managed to translate scientific knowledge into a mortality reduction in patients with acute STEMI. ${ }^{7}$

\section{Código Infarto}

The Código Infarto protocol started being implemented at the Mexican Institute of Social Security (IMSS Instituto Mexicano del Seguro Social) since 2015; it is focused on STEMI diagnosis and reperfusion, and includes two of the seven axes of the A Todo Corazón (At Full Heart) comprehensive care program. ${ }^{7}$ Its purpose is to ensure the diagnosis and treatment of the patient who demands emergency care for acute STEMI, in order for him/her to receive myocardial reperfusion during the first minutes in a more efficient form (accessible, systematized, accurate and humanistic). ${ }^{7}$ The protocol considers the clinical methodological principles of health strategies, ${ }^{8}$ with an institutional and comprehensive approach; ${ }^{9}$ it focuses on monitoring critical activities to achieve its goals, as well as on the measurement of indicators of the management process, which include the reduction of the time for care to be initiated since the onset of the first symptoms, and time to the implementation of any reperfusion mechanism, with fibrinolytic therapy or percutaneous coronary intervention. In both cases, times have been significantly reduced (from 92 to 72 minutes $[p=0.004$ ] and from 144 to 90 minutes [ $p<0.0001$ ], respectively). ${ }^{10}$ This has been possible thanks to face-to-face and online educational training of first contact personnel, effective communication between the three levels of care and to the use of health information systems, such as the Código Infarto Regulating Center, which integrates and organizes information on new cases. Another tool available to the population is IMSS digital app. ${ }^{11}$ In addition, there is also early cardiac rehabilitation since the first 24 to 48 hours. With this, Código Infarto has managed to reduce disability days: from 67.7 to 58.6 days, $\mathrm{p}<0.0001$. $^{12}$

Finally, the National Registry of Acute Coronary Syndrome of the Mexican Institute of Social Security is the largest "real world" study of the country and most Latin American countries; 15,981 individuals diagnosed with AMI-STEMI were enrolled and included in the Código Infarto protocol. ${ }^{13} \mathrm{~A}$ significant reduction in non-reperfused cases was observed (65.2 to $29.6 \%, p<0.0001$ ), mainly due to an increase in percutaneous coronary intervention $(9.4$ to $31.3 \%)$ and fibrinolytic therapy ( 25.5 to $40.1 \%, p<0.0001$ ); in addition, a significant reduction in the time to fibrinolytic therapy application of $35 \%$ was demonstrated (92 versus 60 minutes). ${ }^{13}$ For the first time in Mexico, improvement in reperfusion resulted in a significant mortality reduction: from 28 to $9.4 \%{ }^{1}$ (Fig. 1).

\section{Method}

An analysis of the protocol of care for emergency departments Código Infarto was carried out using the integral method for bioethical discernment, and the reflective equilibrium method for contrasting and clarifying judgments related to epistemic, ethical, legal and medical aspects. ${ }^{14}$ As shown in figure 2, both intervene in the translational process: experimental (T1), clinical (T2), operational (T3) and strategic or health policy-related (T4), and in six phases of knowledge application: generation (F1), implementation (F2), 


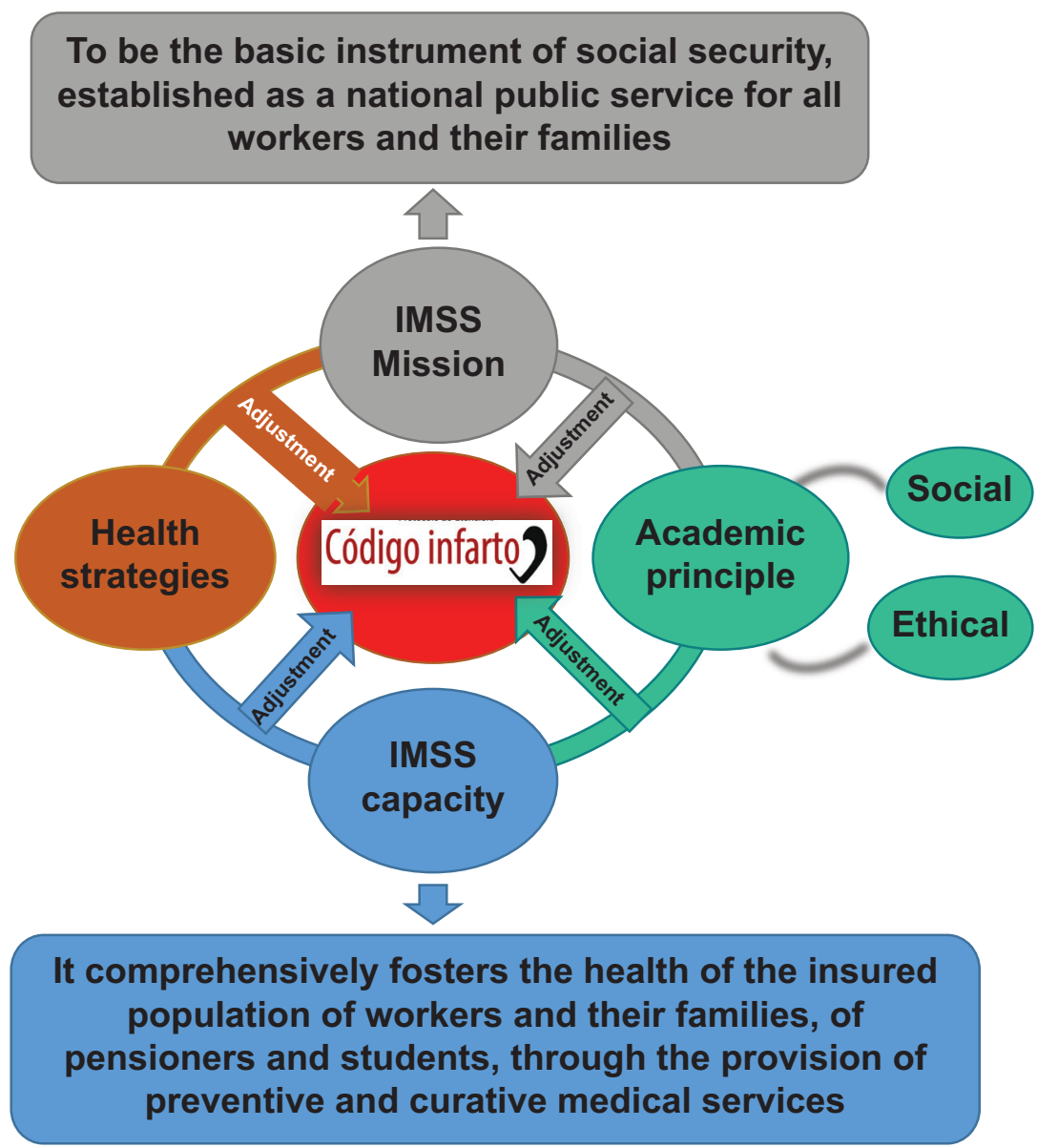

Figure 1. Ethical discernment of the Mexican Institute of Social Security (IMSS - Instituto Mexicano del Seguro Social) Código Infarto protocol.

clinical confirmation (F3), validation of priorities (F4), development of new clinical practice guidelines (F5) and generation of health policies (F6). ${ }^{15}$

\section{Results}

\section{Bioethical discernment of the Código Infarto protocol}

Currently, precision or personalized medicine represents a huge challenge due to its complexity and demand; however with the strengthening of the evidence-based medicine and value-based medicine binomial, ${ }^{16}$ the approach is based on the multiple dimensions of the individual, the health personnel and the social support network (which are essential elements of comprehensive treatment in the health-disease process), which is facilitated by translational medicine, with the ultimate goal of improving the quality of people's health. This leads to the practice of medicine of excellence. ${ }^{17}$
In Mexico, social security is heterogeneous, fractioned in different health institutions, aspiring to provide the "highest possible good" to its affiliates before, during and at the completion of health actions, especially those that reach millions of people..$^{18}$ Código Infarto is based on Burrel's functionalist organizational vision, which starts from a measurable reality and shares aspects such as continuity, feasibility and equity, in search of the benefit of those who suffer from the disease, thus privileging comprehensive cardiology. ${ }^{19}$

\section{Application of the integral method}

The integral method is the ideal, a method of maxima analysis whereby the "good" of the patient is sought. It integrates all three aspects of action: the moral agent, the action itself (based on rights and obligations) and the consequences of the action. It analyzes the "good" from several ethical perspectives. As a ballet dancer who has one foot on the 


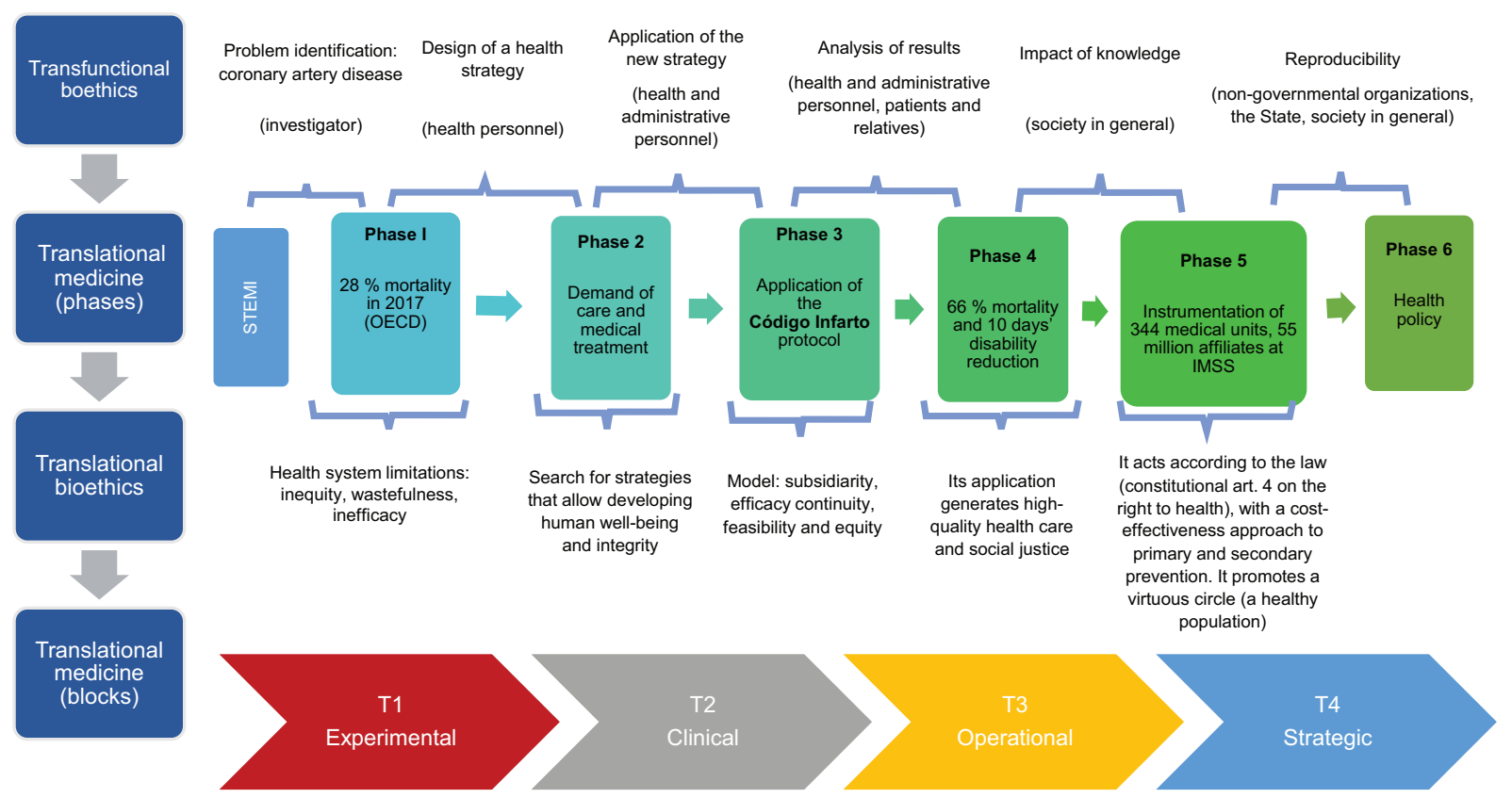

Figure 2. Translational process of the Código Infarto protocol from an ethical perspective. IMSS (Instituto Mexicano del Seguro Social) = Mexican Institute of Social Security.

ground, it represents the different ethical currents determined by empirical circumstances, but with the opposite leg elegantly extended in the air, as a sign of flexibility, looks for new ethical principles that perfect the health professional in his relationship with the patient.

Through five questions, this method enables deliberation, critical reflection and functionality by including the entire health team, the patient and the family members, allowing the treating physician to make a responsible decision, i.e., with knowledge, will and freedom, displaying his/her highest moral power. ${ }^{20,21}$

1. Which is the fact?

In Mexico, myocardial reperfusion occurred in less than $50 \%$ of occasions; the Código Infarto protocol increased its frequency and thus reduced acute myocardial infarction (AMI)-related mortality.

2. What is the "good" that is sought?

A reproducible system that promotes comprehensive patient safety and well-being, with an ethics of maxima that allows developing a "flourishing ethics" of the health personnel to the benefit of the patient.

3. Who are the beneficiaries of the "good"?

Patients, relatives, doctors, the institution and society in general.

4. Who are the main stakeholders?
The patient affected by a disease that puts his/ her life at risk, the health personnel who have ethical responsibility, patient relatives and millions of affiliates covered by the Mexican Institute of Social Security.

5. How are ethical dilemmas identified and stratified? Given that the right to reperfusion is limited in Mexico, health strategies require a sum of values and their implementation; thus, we posed the following dilemma: how does Código Infarto allow advancing towards medicine of excellence?

a) Regarding the aretological aspect: the program calls health personnel and society to adopt a state of solidary consciousness to benefit the patient with acute STEMI, promotes virtues, narrows economic and social differences, safeguards the comprehensive development of both patients and doctors.

b)As for the deontological aspect: health institutions look after compliance with the $4^{\text {th }}$ constitutional article, which indicates that "every person has the right to a healthy environment for his/her development and well-being". Códifo Infarto was born in the bosom of the Mexican Institute of Social Security, the mission of which is the protection of social security.

c) As regards the utilitarian aspect: acute STEMI treatment increases life years gained and their 


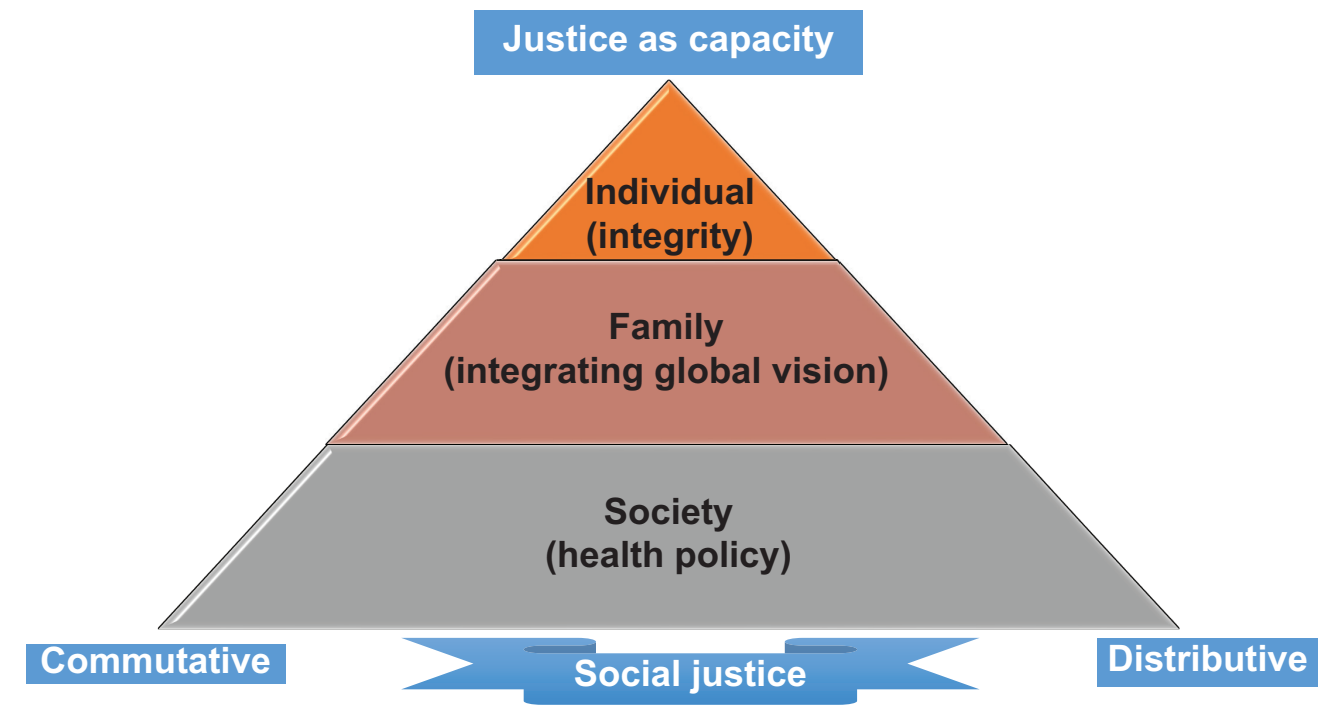

Figure 3. Elements and dynamics of the Código Infarto protocol justice pyramid.

quality; in addition, it decreases the time to diagnosis and treatment, with a reduction in days of stay and work disability.

Código Infarto seeks the "greater good" while preserving the person's integrity, with correct actions and effective and productive consequences.

\section{Código Infarto translational process}

Translational medicine uses basic and clinical scientific discoveries to generate tools for the diagnosis of disease and its treatment. ${ }^{22}$ On the other hand, trans-functional and translational bioethics allow communication based on trust and respect between experts. ${ }^{23}$ Both aim for standards and values to guide towards ethically acceptable biomedical practices with regard to the vital phenomenon, with a critical, radical and universal reflection by a multidisciplinary group that generates ideas, knowledge, concepts, methodologies, experience and instruments to comprehensively solve a common problem, with an effective transfer of biomedical practices axiological structure analysis to the medical (patient bedside, outpatient clinic and operating rooms, among others) and social fields (Fig. 2). ${ }^{24}$

\section{Código Infarto as a health and justice policy in clinical practice}

Health is a common good and a priority for countries, globally. The OECD proposed that Mexico should build an equitable, efficient and sustainable health system; offer continuous, personalized, proactive health care, with the development of standards and guidelines. ${ }^{25}$ In this sense, the $4^{\text {th }}$ constitutional article, article 2 of the General Statute of Health and the Mexican Institute of Social Security Law stipulate that health protection has physical and mental well-being of the person as its purpose, in order to contribute to the full exercise of his/her capacities., ${ }^{5,26}$ In addition, strategic actions focused on health policies must be the social bond between well-being and the community.

With the above, justice is sought, understood in the Aristotelian sense as the perfect virtue, under its two forms: distributive justice, which seeks to regulate the distribution of goods and assets in the community; and commutative justice, which regulates the relationship between individuals. Social justice adds dynamism to legal justice and highlights distributive justice; in addition, it ensures the respect and promotion of rights for everyone. ${ }^{27}$ This is how it moves towards justice as a capacity, which takes people into account and promotes their flourishing and fullest potential (Fig. 3).

\section{Discussion}

Inequality is an obstacle for a country to reach the peak of its potentialities. In Mexico, $44.4 \%$ of the population lives in poverty (National Council for Social Development Policy Evaluation, 2018) ${ }^{28}$ and, in 
contrast, $75 \%$ have obesity or overweight; thus, social policy oscillates between deficit and excess. Therein lies the importance of recognizing the significance of individual and collective responsibility in matters of health.

There are efforts in the world to raise the quality of STEMI care, such as the Infarctus du Myocarde program in France, which uses efficacy and safety indicators, ${ }^{29}$ the Code STEMI protocol in Canada, which operates 24-hour long, ${ }^{30}$ and Lifeline, for the rapid care of acute STEMI, of the American Heart Association. ${ }^{31}$ With Código Infarto, Mexico is one of the pioneers in the protocols for acute STEMI care at emergency departments. Its rules provide strength and direction to participants, generate awareness on regulations, make it clear that their omission only delays medical care and increases complications in patients who can benefit from the application of the protocol.

However, these strategies have not been analyzed from the perspective of translational bioethics, which is a vector of change that implies stopping to think, explore and discuss the different stages of the translational process, which include scientific discovery, implementation of the evidence-based medicine-value-based medicine binomial through clinical practice guidelines and its impact on the population, which are key principles for practicing medicine of excellence.

Ethics recognizes justice as one of the basic principles between individuals, ${ }^{32}$ and when it is incorporated to institutionalized bioethics, it turns into a tool to implement health programs. One example are the Pan American Health Organization global health programs, where bioethics is essentially understood as a catalyst for the discussion and analysis of problems and dilemmas. ${ }^{33}$

In Mexico, this is the first article to analyze a Mexican cardiology health strategy from the translational bioethics perspective. The discernment of values, health management and scientific knowledge are key to the efficiency of this type of initiatives and to achieve for medicine to transmit the value life.

\section{Acknowledgements}

To Engineer Rodrigo Campos Silva and Mercedes Ramos Velasco for the graphic elements. To the Mexican Institute of Social Security and to the trans-functional ethics group, for the fruitful discussions.

\section{Conflict of interests}

The authors declare that they have no conflicts of interest.

\section{Funding}

The authors did not receive any sponsoring for carrying out this article.

\section{Ethical disclosures}

Protection of human and animal subjects. The authors declare that no experiments were performed on humans or animals for this research.

Confidentiality of data. The authors declare that no patient data appear in this article.

Right to privacy and informed consent. The authors declare that no patient data appear in this article.

\section{References}

1. Organisation for Economic Cooperation and Development [Internet]. France: Health at a Glance; 2019.

2. Instituto Nacional de Estadística y Geografía. Características de las defunciones registradas en México durante 2017. Mexico: Instituto Nacional de Estadística y Geografía; 2018.

3. Consejo Nacional de Evaluación de la Política de Desarrollo Social [Internet]. Mexico: Evaluación estratégica de protección social; 2018.

4. Palomino P, Grande M, Linares M. The social determinants of health inequalities and exclusion in XXI ${ }^{\text {st }}$ century societies. Rev Int Sociol. 2014;72:71-91.

5. Gómez-Dantés O, Sesma S, Becerril V, Knaul F, Arreola H, Frenk J. Sistema de salud de México. Salud Publica Mex. 2011;53:s220-s232.

6. Shiguetomi-Medina J. La medicina traslacional: una disciplina emergente. Rev Mex Ortop Ped. 2013;15:64-67.

7. Borrayo G, Pérez G, Arriaga D, Martínez OG, Almeida, Ramírez E, et al. Protocolo para atención de infarto agudo de miocardio en urgencias: Código Infarto. Rev Med Inst Mex Seg Soc. 2017;55:233-246.

8. Haynes RB, Sackett DL, Guyatt GH, Tugwell P. Clinical epidemiology, how to do clinical practice research. USA: Lippincott Williams \& Wilkins; 2006.

9. Instituto Mexicano del Seguro Social [Internet]. México: El Código Infarto del IMSS, con la mayor cobertura en América Latina; 2016.

10. Arriaga J, Pérez G, Borrayo G. Dimensiones de calidad enfocadas en el protocolo de atención Código Infarto. Rev Med Inst Mex Seguro Soc. 2017;55:382-387.

11. Secretaría de Salud [Internet]. Mexico: Sistemas de Información en Salud ; 2020.

12. Borrayo G, Madrid A, Arriaga R, Ramos MA, García J, Almeida E. Riesgo estratificado de los síndromes coronarios agudos. Resultados del primer Renasca-IMSS. Rev Med Inst Mex Seguro Soc. 2010;48:259-264.

13. Borrayo G, Rosas M, Ramírez E, Saturno G, Estrada J, Parra R, et al. STEMI and NSTEMI: real-world Study in Mexico (RENASCA). Arch Med Res. 2018;49:609-619.

14. Ortiz-Flores J. El equilibrio reflexivo en el pensamiento bioético de Rodolfo Vázquez. México: Instituto de Ciencias Jurídicas/Universidad Nacional Autónoma de México; 2017.

15. Trochim W, Kane C, Graham MJ, Pincus HA. Evaluating translational research: a process marker model. Clin Transl Sci. 2011;4:153-62

16. Peile E. Evidence-based medicine and values-based medicine: partners in clinical education as well as in clinical practice. BMC Med. 2013;11:40.

17. Sueiras P, Romano-Betech V, Vergil A, De Hoyos A, Quintana S, Ruddick W, et al. Today's medical self and the other: challenges and evolving solutions for enhanced humanization and quality of care. PLoS One. 2017; 12:e0181514.

18. Gracia D. Fundamentos de la bioética. Spain: Eudema; 1989. 
19. Burrell G, Morgan G. Sociological paradigms and organisational analysis. United Kingdom: Ashgale Publishing; 1979.

20. Altamirano M, Garduño J, García MC, Muñoz O, editors. Discernimiento de dilemas éticos en la práctica clínica. In: Ética clínica una perspectiva transfuncional. Mexico: Corinter; 2006.

21. Cruz M. Medicina traslacional. Gac Med Mex. 2017;153:547-549.

22. Guerra LR. Por una bioética sin adjetivos II. Bioética, interdisciplinariedad y sociedad plural. ARS Med. 2008:37:137-146.

23. Olivé L. La bioética: Latinoamérica y la diversidad cultural. Mexico: Instituto de Investigaciones Jurídicas/Universidad Nacional Autónoma de México; 2019.

24. Hostiuc S, Moldoveanu A, Dascalu ML. Unnthorsson R, Johanneson OI, Marcus I. Translational research the need of a new bioethics approach J Transo Med. 2016,14:16.

25. Ley del Seguro Social. Mexico: Diario Oficial de la Federación; 2019.

26. Contrato colectivo de trabajo 2019-2021. Mexico: Sindicato Nacional de Trabajadores del Seguro Social/Instituto Mexicano del Seguro Social; 2019.
27. Barnes J. The complete works of Aristotle. USA: Princeton/Bollingen Foundation; 1984.

28. Consejo Nacional de Evaluación de la Política de Desarrollo Social [Internet]. Mexico: Medición de la pobreza 2008-2018;2019.

29. Haute Autorité de Santé [Internet]. France: Indicateurs de pratique clinique. Infarctus du myocarde (IDM); France: HAS; 2012. Available at: https://www.has-sante.fr/upload/docs/application/pdf/2012-07/04_indicateurs idm actualisation 2012 vf.pdf

30. University of Ottawa Heart Institute [Internet]. STEMI Program; 2014. Available at: https://www.ottawaheart.ca/healthcare-professionals/regional-national-programs/stemi-program

31. American Heart Association [Internet]. Mission: Lifeline; 2020

32. López M. Ética profesional y complejidad: los principios y la religación. Perfiles Educativos. 2013;35:43-52.

33. Lolas $F$. La bioética en el contexto de los programas globales de salud. Pan Am J Public Health. 1999;6:65-68. 